\title{
Synchronization of mechanisms for realizing the interests of the population in rural territories
}

\author{
Seyidullah Khanmagomedov, Mukail Mukailov, Nazima Ulchibekova*, Abdulkadi Yusufov, \\ and Tamila Ashurbekova
}

Dagestan State Agrarian University named after M.M. Dzhambulatova, M. Gadzhieva street, 180, 367032 Makhachkala, Russia

\begin{abstract}
The subject of the research is an expert analytical assessment of the arguments for enhancing the manifestation of interest and the adoption of programs by the country's top authorities to improve agricultural policy, accelerate the development of conditions and mechanisms for the implementation of socio-economic problems and interests of the population of rural areas. Using the methods of economic and statistical analysis and logistic and expert assessment, chronic and urgent problems in agro-industrial production, in social engineering, stimulating the interests of the rural population and developing new mechanisms for their implementation are analyzed. Results. The assessment of the state of social engineering infrastructure at the level of the region, federal district and country is given. A model of the mechanism for motivating and realizing the socio-economic interests of the population of rural areas, the author's presentation of the visions of experts, agricultural scientists on the role of the state and modern agricultural policy in the effective development of agricultural sectors and improving the quality of life in rural areas are proposed. Conclusions. The importance of the adopted new State Program for the integrated development of rural areas was noted, priority directions and ways of developing the mechanism for realizing socio-economic interests, increasing the level of employment and consumer ability of the rural population, etc.
\end{abstract}

\section{Introduction}

The main interests of the population in rural areas are presented in the form of perceived needs in providing social and economic benefits.

The implementation (solution) of the aggregate (especially economic) interests of the population (individual, group, public) due to their heterogeneity in territorial distribution necessitates synchronization and objective smoothing of certain contradictions between participants in social reproduction. They can be combined according to certain criteria (territorial, social, economic, individual) in the formation and adaptation of public institutions (power structures, administrative-territorial entities, industry complexes, public organizations, business entities) and the rural community.

\footnotetext{
*Corresponding author: n.nazima@mail.ru
} 
The mechanism for their actualization and solution includes the implementation of functions and approaches aimed at coordinating, consolidating, regulating, reproducing and motivating the subjects of rural areas, forming an adequate system of social security, education, healthcare, information and regulatory support.

As tools for realizing the economic interests (the most basic and important) of the population, experts suggest focusing on socio-economic, financial, credit, tax and antimonopoly policies, a system of adequately worthy state support within the framework of various target programs in the country and its regions.

Fulfilling the instructions of the President of the Russian Federation V.V. Putin (Message to the Federal Assembly dated 20.02.2019) the Government of the Russian Federation, to replace the departmental program "Sustainable Development of Rural Areas", adopted the Resolution of the Government of the Russian Federation No. 696 of May 31, 2019. "On the approval of the state program" Comprehensive development of rural areas" [4].

The implementation of the new State Program provides (for 2020-2025) about 2.3 trillion rubles of funding, of which 1.1 trillion rubles (about 48\%) - allocations from the Federal budget. The volume of funds from extra budgetary sources is also expected to be about 1.1 trillion rubles. Allocations from the consolidated budgets of the constituent entities of the Russian Federation are envisaged in the amount of about 1.7 trillion. rubles.

By analogy with the above Resolution, the Republic of Dagestan adopted its Government Resolution No. 272 dated October 25, 2019. "On the approval of the state program" Comprehensive development of rural areas of the Republic of Dagestan "for the period 2020-2025 [5]. ]. For the implementation of this program, 37 billion rubles of budgetary funds are provided, incl. from the federal budget - 35.0 billion rubles $(94.6 \%)$, the republican budget - 1.8 billion rubles (4.9\%), local budgets - 121.1 million rubles $(0.3 \%)$. In addition, the forecasted (expected until 2025) amount of allocations from extrabudgetary sources will amount to 3.3 billion rubles.

The main task of the adopted State Programs is to radically change the socio-economic situation in rural areas: to increase the level of employment and the quality of life of the rural population; to accelerate the development of engineering and social infrastructure in rural areas; to provide an integrated approach and synchronization of actions of all interested structures (public and private) in the stable growth of the well-being of villagers [15].

\section{Results}

In recent years, the leadership of the country and its constituent entities, as well as the governing bodies of the agro-industrial complex of all levels, have taken certain encouraging measures to regulate migration processes and social and engineering development of rural areas, etc. However, the village still badly needs a really working, intelligible and comprehensive program that ensures reliable growth of income and employment of the rural population, improves the quality of demographic processes, develops a system of rural cooperation, overcomes the degradation of human capital in the countryside, etc. $[6,7,10,18,19,20]$.

In the Republic of Dagestan the agrarian sector of the economy has been and remains the main source of livelihood for a significant part of the population (more than $50 \%$ ), the main component of the economy, as a whole, and an important environment for the formation, preservation and development of national culture and spirituality. To overcome the crisis in the socio-economic sphere of rural areas, today it is necessary to develop and implement a complex of long-term target programs: socio-economic development of the countryside; overcoming rural poverty; increasing employment and income of the rural 
population; development of rural self-government and stimulation of the development of non-agricultural business in rural areas, etc. They should be focused on the implementation of vital socio-economic functions: demographic, socio-cultural, environmental, recreational, social control over territories, support and outstripping the development of system-forming and import-substituting industries of food production, economically rational territorial distribution and ensuring the competitiveness of agro-industrial brand production, stimulating the processes of mastering innovative technologies and expanding integration ties, etc.

Table 1. Indicators of social and engineering development of rural areas

\begin{tabular}{|c|c|c|c|}
\hline & \multirow[b]{2}{*}{2010} & \multicolumn{2}{|c|}{$2014-2018$} \\
\hline & & $\begin{array}{l}\text { Average annual } \\
\text { values }\end{array}$ & in $\%$ to 2010 \\
\hline \multicolumn{4}{|c|}{ 1. Commissioning of residential buildings by the rural population (thousand sq. M.) } \\
\hline Russian Federation (RF) & 14737 & 22140 & 150,2 \\
\hline $\begin{array}{l}\text { North Caucasus Federal District } \\
\text { (NCFD) }\end{array}$ & 901,7 & 1576,9 & 174,9 \\
\hline incl. Republic of Dagestan (RD) & 494,8 & 526,9 & 106,5 \\
\hline \multicolumn{4}{|c|}{ 2. Entering educational institutions (academic places) } \\
\hline $\mathrm{RF}$ & 20208 & 21650 & 107,1 \\
\hline NCFD & 3404 & 8991 & 264,1 \\
\hline RD & 1906 & 1779 & 77,6 \\
\hline \multicolumn{4}{|c|}{ 3. Entering preschool institutions (places) } \\
\hline $\mathrm{RF}$ & 3465 & 20984 & 605,6 \\
\hline NCFD & 1535 & 1821 & 118,6 \\
\hline RD & 345 & 688 & 199,3 \\
\hline \multicolumn{4}{|c|}{ 4. Commissioning of gas networks in rural areas $(\mathrm{km})$} \\
\hline $\mathrm{RF}$ & 11069 & 7083 & 64,0 \\
\hline NCFD & 257 & 268 & 104,2 \\
\hline RD & 14 & 73 & 519,6 \\
\hline
\end{tabular}

Source: Collection of the Ministry of Agriculture of the Russian Federation "Agroindustrial Complex of Russia" (author's data processing).

For an analytical assessment of the problems of rural areas, we used the available official data of the Ministry of Agriculture of the Russian Federation (Table 1) on the commissioning of social engineering facilities in comparison with the average for 20142018 (due to large annual fluctuations) with their level in 2010.

In addition to the commissioning of gas networks, from the given positions of the construction of infrastructure facilities in the country there is a good dynamics, and as for the commissioning of preschool institutions, the growth was more than 6 times (in the Republic of Dagestan - less than 2 times).

Over the past three years, thanks to the growth of the budget of the Republic of Dagestan from 100 billion to 170 billion rubles (federal budget support), only to provide for the population of the republic (especially in rural areas) within the priority project "My Dagestan - My Water" has been spent more than 5.5 billion rubles, under the project " 100 schools" - 1.3 billion rubles have been financed for repair work, according to the project "My Dagestan - my roads" - several billion rubles, within the framework of the project "Local Initiatives" for social and engineering infrastructure, the amount of financing exceeded 700 million rubles, etc. 
The process of realizing the social, engineering and economic interests of the rural population in the constituent entities of the country is limited by the peculiarities of the development of individual rural areas (spatial, social, ethnic, historical - as basic for the reproduction of the rural community), due to the specifics of the functioning of the branches of agricultural production [17, 18].

In this regard, it is advisable to update the selection of elements, tools and methods for creating favorable conditions for the successful implementation of the socio-economic interests of the rural population.

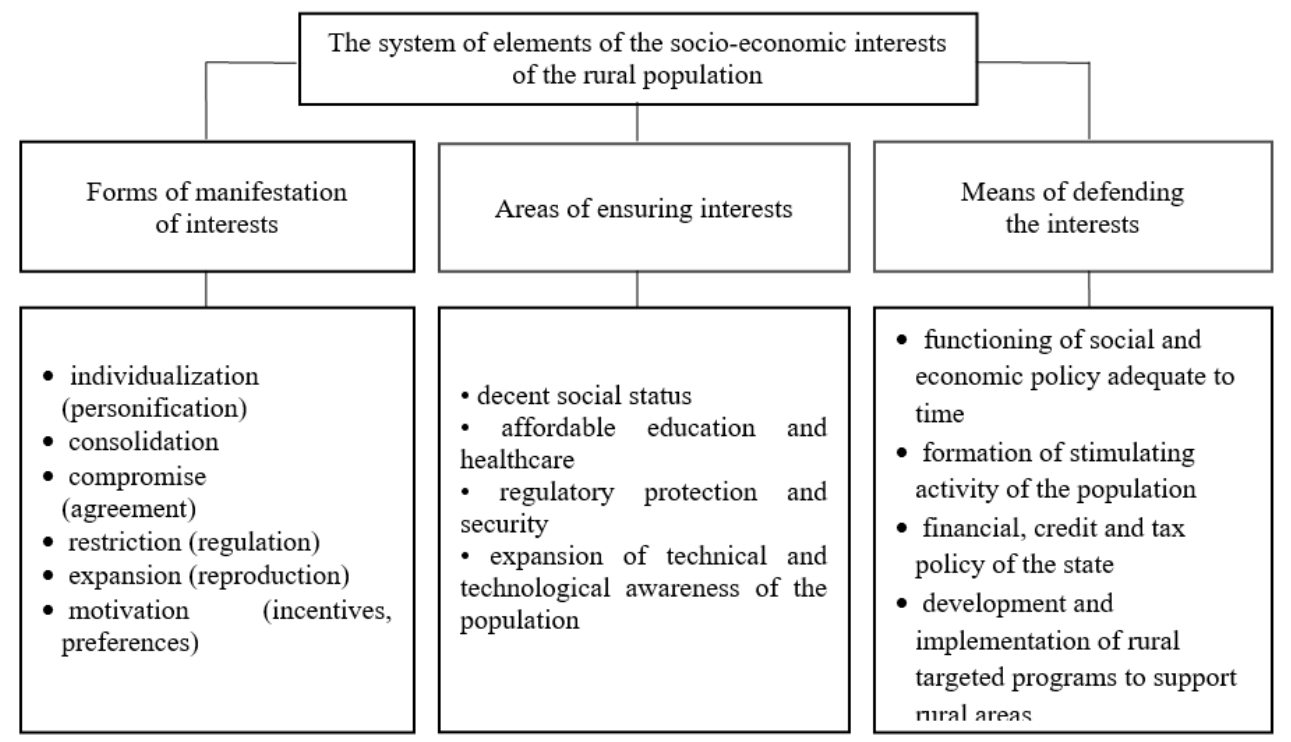

Fig. 1. Model of the structure of the mechanism of motivation and implementation of the socioeconomic interests of the population of rural areas (author's development)

The proposed model of the structure of the mechanism for realizing the interests of the population of rural areas (Fig. 1) indicates the main functional elements of the system of social security, education, health care, security, legal, regulatory, technological and information support of the interests of the rural population. The relevance, versatility and complexity of the implementation of this model presupposes the complex use of economic, social, antitrust, financial and credit and tax policies, the system of state support and various targeted programs, as well as a balanced approach to economic, administrative and political methods to consolidate efforts to achieve the dynamics of success.

The conditions for the functioning of the mechanism for the realization of the interests of the rural population and the action of the directions of its evolutionary improvement at the federal and regional level largely determines the transition from the sectoral model of rural development to the territorial one, when the priority of public administration has become not agriculture as the most important branch of the national economy and food security, but rural areas, which leads to a gap in positions in the strategy of their development.

The consequences of the gap in the strategy for the integrated development of the agroindustrial complex and rural areas are visible in practice - the self-elimination of economic entities (especially large and economically successful business structures) from active participation in solving social problems of villagers in the rural areas under their control, as well as underdevelopment (and, then and the absence) of an effective system of publicprivate partnership in the agro-industrial sphere of food production [12,17,22]. 
Experts assess the effectiveness of the existing state policy of rural development ambiguously and with some criticism: "... political decisions in the field of economic and related social development, in particular in agriculture, often contradict the objective laws of this development and are based on subjective ideas", further ".. it was believed that all state programs for the development of the agro-industrial complex were focused on the development of effective, sustainable and competitive agricultural production ..., an increase in the quality of life of the rural population, the formation of conditions for the realization of its economic interests. But, in reality, there was a process of destruction of the rural economy and degradation of the social sphere of the village. Hopes for a rapid rate of diversification of the rural economy did not justify themselves "[17, 19].

Even more categorical, the head of the Center for Agrarian Problems of the Institute of the USA and Canada of the Russian Academy of Sciences O. G. Ovchinnikov, who notes: "In recent years, praise for Russian agriculture has been heard from the high stands with growing pathos. And if to be objective, it should be admitted that there are grounds for this. First of all, this is the statistics of the growth of agricultural production volumes ". He further writes that "... comparing the growth of production with 2000 - the year of the lowest point of the" bottom "of the grandiose failure experienced by the agroindustry after shock therapy in the early 90 s of the last century, is some elements of deceit ... and ... if we compare the current production volumes with those that took place in 1990, it turns out that everything is not so optimistic" [13].

In fact, the existing statistical data (Table 2) shows that in 2018 for the production of such types of food products as grain, potatoes, milk and eggs in the country have not yet reached the level of their volumes in 1900. During the same period, in the Republic of Dagestan good growth was achieved in all the above types of products.

In the Russian Federation in 2018 compared to 2000 (called a disastrous year), potato and milk production reached the previous level by only $75.6 \%$ and $94.7 \%$, respectively. Similarly, in the Republic of Dagestan during the analyzed period, for all types of food products (except for the production of eggs) significant increases in their production were achieved (from $32 \%$ to $364.2 \%$ ).

Table 2. Dynamics of production of agricultural food products (RF/ RD, million tons)

\begin{tabular}{|c|c|c|c|c|c|c|}
\hline \multirow{2}{*}{ Types of products } & \multirow{2}{*}{1990} & \multirow{2}{*}{2000} & \multirow{2}{*}{2010} & \multirow{2}{*}{2018} & \multicolumn{2}{|c|}{2018 in $\%$ n.: } \\
\hline & & & & & 1990 & 2000 \\
\hline \multirow[t]{2}{*}{ Grain } & 116,7 & $\underline{65,4}$ & $\underline{60,4}$ & 112,3 & $\underline{96,2}$ & 171,7 \\
\hline & $\overline{0,352}$ & 0,232 & $\overline{0,210}$ & $\overline{0,360}$ & 102,3 & 155,2 \\
\hline \multirow{2}{*}{ Potatoes } & $\underline{30,8}$ & 29,5 & $\underline{18,5}$ & 22,3 & $\underline{72,4}$ & 75,6 \\
\hline & $\overline{0,135}$ & 0,105 & $\overline{0,307}$ & 0,356 & 263,7 & 339,0 \\
\hline \multirow{2}{*}{ Vegetables } & $\underline{10,3}$ & $\underline{10,8}$ & $\underline{11,0}$ & 13,7 & 133,0 & 126,9 \\
\hline & $\overline{0,568}$ & $\overline{0,310}$ & $\overline{0,948}$ & $\overline{1,439}$ & 211,6 & 464,2 \\
\hline \multirow{2}{*}{$\begin{array}{l}\text { Livestock and poultry (in } \\
\text { killed weight) }\end{array}$} & 10,1 & $\underline{4,4}$ & $\underline{7,2}$ & $\underline{10,5}$ & 104,0 & 238,6 \\
\hline & 0,078 & 0,053 & 0,087 & 0,148 & 189,7 & 279,2 \\
\hline \multirow{2}{*}{ Milk } & $\underline{55,7}$ & 32,3 & $\underline{31,5}$ & $\underline{30,6}$ & $\underline{54,9}$ & $\underline{94,7}$ \\
\hline & 0,358 & 0,279 & 0,605 & 0,893 & 249,4 & 320,1 \\
\hline \multirow{2}{*}{ Eggs, bln. } & $\underline{47,5}$ & $\underline{34,1}$ & $\underline{40,7}$ & $\underline{45,0}$ & $\underline{94,7}$ & 132,0 \\
\hline & 0,240 & 0,245 & 0,214 & 0,245 & 102,1 & 100,0 \\
\hline
\end{tabular}

Agricultural scientists pay attention to the current state of saturation, high competition and localization of consumer markets, the conditions for the underdevelopment of the procurement and supply and marketing cooperation system, low effective demand of the rural population, the processes of degradation of human capital and low labor activity of the population in rural areas, etc., which hinder the growth of incomes and the rationalization of the food structure of the villagers $[17,19,21]$. 
In order to modernize the model of complex motivation for the labor activity of the rural population (including within the framework of their self-employment), the experts suggest highlighting the forms of its manifestation as traditional (historically formed labor behavior), ethical (system of social values and social duty), administrative ( control of compliance with social norms of labor behavior), economic (management of the economic needs of an individual), technological (implementation of labor functions based on the availability of professional experience and qualifications) $[9,21]$.

Today, the role of the state in increasing the efficiency of the use of tools aimed at adjusting the functioning system of economic and social needs of the rural population is very relevant. These include improving the system of material and moral values, fight against alcoholism and social dependency, reducing the tax burden on rural business entities, preferential access to credit resources for agricultural producers, adequate development of the social and engineering infrastructure of rural settlements, ensuring employment and self-employment of the population, diversification of agricultural production and rural economy, solving the problem of staffing production systems with the transfer of agricultural industries to an innovative path of their development, etc.

In this regard, the President of the Russian Federation V. Putin at the meeting of the State Council (26.12.2019, Moscow) once again pointed out the issues that require special attention. These are, first of all, the issues of the economy of rural production, a comfortable environment for life, conditions for improving the well-being of people in the countryside and the level of provision of rural areas with all types of amenities (water supply, heating, gas, housing and communal services, social, educational, medical institutions, road network).

In May 2020, the state program "Comprehensive Development of Rural Areas" was adopted. It aims to support important initiatives and projects that are relevant to specific villages, townships, their residents, local business and agricultural entrepreneurship.

It can be expected that the updated Government of the Russian Federation, together with regional authorities, will determine effective management decisions in the implementation of the instructions of the head of state.

\section{Conclusions}

The main and priority directions of the development of the mechanism for realizing the social and economic interests of the rural population can be systematized and concentrated in the context of the consistent solution of problems:

- active formation of the necessary conditions for the realization of the interests of the population (adjusting the agrarian and economic policy of the state and the system of meeting the needs of the rural population, adequate to the requirements of the time, the development of social responsibility of public-private partnerships in reducing the level of social and economic inequality in the countryside, etc.);

- dynamically sustainable development of the rural economy (worthy support of all forms of management, development of rural consumer cooperation, diversification of agricultural production, stimulation of the actual creation of additional jobs for the rural population, training of qualified personnel capable of working in conditions of development of intensive and innovative technologies in the agricultural sector, etc. );

- increasing the consumer ability and quality of life of the rural population (adequate growth of the minimum wage, motivation for productive labor activity, tax incentives, moderately limited tariffs for services of natural monopolies, physical and economic accessibility of consumer goods in the markets, accelerated development of the social and engineering structure of rural settlements, achieving a balance between 
the subjects of economic relations: employer - employee, owner - tenant, producer consumer, etc.).

For the Republic of Dagestan, where small forms of farming (peasant farms and private household plots) account for on average more than $80 \%$ of agricultural products of its total volume in the region, the implementation of the new State Program "Comprehensive Development of Rural Areas of the Republic of Dagestan" is of paramount importance for the successful functioning of the agrarian economy and significant improving the quality of life of the rural population.

Ensuring sustainable social and economic development of rural areas and improving the quality of life of the region's villagers are multifaceted and complex problems. Economic growth requires the accompaniment of modern investment and innovation structural shifts, as well as taking into account competitive advantages and prospective development priorities, possible risks and restrictions, the volume of financial flows to the regional (and sectoral) economy, etc. And to regulate social processes in rural areas in the region, more it is necessary:

- increasing the level of medical care, reducing the mortality rate, increasing the life expectancy of the population;

- an increase in real incomes of the population, a decrease in the level of property stratification in society and unemployment of the able-bodied population;

- increasing the motivation of skilled labor, the prestige of employment in the use of modern technologies, science and best practices (to secure rural youth and skilled workers);

- strengthening the role of small processing industries in rural areas, which will allow accumulating procurement, processing and marketing processes for food products (a tool for internal diversification of the agricultural system in rural areas, expanding the relationship of agricultural producers, improving the employment of the population);

- examination of options for merging (combining) rural production activities with other technologically unrelated to the agro-industrial complex enterprises, combines, firms (external diversification). One of the options for external diversification is the development of rural (agrarian) tourism, as a result, such activities as culture, health care, ecology, transport, sports, and especially important - the employment of the rural population, etc. will be interconnected.

All of the above stipulates the need for a synchronous course of socio-economic processes, which should lead to the provision of dynamically sustainable shifts in improving the quality of life of the population of rural areas of the country and its regions.

\section{References}

1. Message of the President of the Russian Federation to the Federal Assembly (2019)

2. Doctrine of food security of the Russian Federation (2020)

3. Decree of the Government of the Russian Federation No. 98 of February 8, New edition of the state program for the development of agriculture and regulation of markets for agricultural products, raw materials and food (2019)

4. Resolution of the Government of the Russian Federation No. 696 dated May 31, "On the approval of the state program" Comprehensive development of rural areas " (2019)

5. Resolution of the Government of the Republic of Dagestan No. 272 dated 25.10, "On the approval of the state program" Comprehensive development of rural areas of the Republic of Dagestan " (2019)

6. A.I. Altukhov, Economy of agricultural and processing enterprises, 7 (2017) 
7. K. Babkin, APK: economics, management, 5 (2019)

8. Bulletin on current trends in the Russian economy, https:/ac.gov.ru/

9. L.F. Kormakov, Economy of agricultural and processing enterprises, 4 (2018)

10. E.N. Krylatykh, E.Yu. Frolova, Economics of agricultural and processing enterprises, 3 (2018)

11. V. Reimer, International Agricultural Journal, 2 (2016)

12. S. Nebrenchin, The Economist, 2 (2018)

13. O.G. Ovchinnikov, Economics of agricultural and processing enterprises, 3 (2018)

14. Russia and the world: food

15. Heading: News

16. Yu. Severina, A. Ulezko, Economy of agriculture in Russia, 9 (2017)

17. I. Semenova, A. Ulezko, Economy of agriculture of Russia, 2 (2017)

18. N.V. Chugunova, S.A. Ignatenko, Socio-economic geography, Bulletin of the Association of Russian Geographers-Social Scientists, 5 (2016)

19. I.N. Buzdalov, K.S. Tikhonkov, Economic horizons, 4(30) 92016)

20. I. Ushachev, A. Kolesnikov, APK: economics, management, 5 (2019)

21. I.G. Ushachev, APK: economics, management, 3 (2019)

22. V.A. Tsvetkov, Problems of market economy, 3 (2017)

23. F.M. Aliev, D.G. Imashova, P.M. Sheykhova, P.M. Kamalova, Contributions to Economics, 9783319552569, 69 (2017)

24. M.A. Filin, S.Y. Maksimova, E.B. Murzageldieva, Z.Z. Tsakhaeva, D.A. Shaydaeva, Growth poles of the global Economy: emergence, changes and future perspectives: Lecture Notes in Networks and Systems, Plekhanov Russian University of Economics, 969 (2020) 